\author{
床面の側方移動に対する外乱予告の有無が \\ 下肢筋の筋活動に与える影響
}

\title{
Effect of disturbance instruction against lateral floor transition on muscle activity of lower limb muscles
}

\author{
三好 彩苗 ${ }^{1)}$, 下西 花音1), 安彦 鉄平 ${ }^{1)}$, 山口 秀明 ${ }^{2)}$ \\ 松尾 奈々 ${ }^{1)}$, 岩瀬 弘明 ${ }^{3)}$, 兒玉 隆之 ${ }^{1)}$
}

Sanae Miyoshi, Kanon Shitanishi, Teppei Abiko, Hideaki Yamaguchi

Nana Matsuo, Hiroaki Iwase, Takayuki Kodama

\begin{abstract}
要旨：本研究の目的は，側方への床面移動に対する外乱の夕イミング予告の有無が下肢筋 の筋活動に与える影響を検証することである。対象は，若年健常成人男性13名とした。測 定は，右側方向へ床面を移動させる課題に対して予告有条件と予告無条件の 1 施行目にお ける下肢筋の外乱前の安静時筋活動量（以下，\%IEMG-rest），外乱後の最大筋活動量（以 下，\%IEMG-max)および筇反応時間を測定し，各測定值を比較した。その結果，\%IEMG -max は予告無条件と比較して予告有条件の 1 施行目において左中殿筋，右前脛骨筋およ び右長腓骨筋で有意な高い值を示した。筋反応時間に関しては，予告無条件と比較して予 告有条件において左中殿筋，左長内転筋および右長腓骨筋において有意に短縮した。％ IEMG-rest は，いずれの筋においても条件間による差は認められなかった。以上のことか ら，若年健常者は外乱のタイミング予告を与えることで，外乱に対して姿勢制御する筋の 最大筋活動量が増加し，筋反応時間が短縮することが明らかとなった。
\end{abstract}

キーワード：姿勢制御, 筋電図, 外乱予告, 側方外乱刺激

\begin{abstract}
The purpose of this study was to examine the effect of disturbance instruction against lateral floor transition on muscle activity of lower limb muscles. The study included 13 young healthy adult males. The resting muscle activity before the disturbance (\%IEMG-rest), maximum muscle activity after the disturbance (\%IEMG-max), and muscle reaction time of the lower limb muscles in the condition with and without disturbance instruction of moving the floor to the right side were measured. \%IEMG-max showed significantly higher muscle activity in the left gluteus medius, right tibialis anterior, and right peroneus longus in the condition with the instruction than that in the condition without the instruction in the first trail. Regarding the muscle reaction time, the left gluteus medius, left adductor longus and right peroneus longus started activity significantly earlier in the condition with the instruction than that in the condition without the instruction. For any of the muscles, no difference was observed in \%IEMG-rest between the conditions. These results indicate that, in young healthy subjects, \%IEMG-max that control posture in response to disturbance increased by the disturbance instruction, and the muscle reaction time is earlier.
\end{abstract}

Key words: postural control, electromyogram, instruction, lateral floor transition

\footnotetext{
受付日：2021年 1 月 6 日, 採択日：2021年 3 月 1 日

京都橘大学健康科学部理学療法学科 干607-8175 京都府京都市山科区大宅山田34

TEL : 075-571-1111 E-mail: abiko@tachibana-u.ac.jp

Department of Physical Therapy, Faculty of Health Sciences, Kyoto Tachibana University

Yamada-cho Oyake Yamashina-ku Kyoto 607-8175 Japan

Phone: +81-75-607-8175

2) アイシン精機株式会社

AISIN SEIKI Co.,Ltd.

3) 神戸国際大学リハビリテーション学部理学療法学科

Department of Physical Therapy, Faculty of Rehabilitation, Kobe International University
} 


\section{I 、はじめに}

外乱に対する姿勢制御には，主に予測的姿勢制御と 代償的姿勢制御の 2 つがある ${ }^{1)}$ 。予測的姿勢制御とは, 素早い動作を行う自発的な外乱や環境からの外乱が身 体に加わる前の反応であり，フィードフォワード制御 のひとつである。代償的姿勢制御とは，姿勢反射や姿 勢反応, 予期せぬ変化へのすばやい反射など外乱刺激 によって生じた姿勢の崩れを調整する反応でフィード バック制御を意味する。これら 2 つの姿勢制御が適切 に働くことで, 外部環境に適応しながら, バランスを 保持して動作や移動が可能となる。この姿勢制御に影 響を与える要因には, 視覚の制限 ${ }^{2)}$, 足の幅 ${ }^{3)}$ や手すり ${ }^{4)}$ などの姿勢の条件, 計算や選択反応課題などの認知課 題 $^{5-6)}$, 外乱の夕イミングや方向などの予告 ${ }^{7-11)}$ な゙が 示されている。

外乱予告に関する先行研究として, Ackermann ら は床面が上方に傾斜するタイミングを教示することで, 姿勢の補償に作用する筋活動の応答が早まることを示 した。Claudino ら ${ }^{9)}$ は, 上部体幹に対して外側方向へ の外乱を加える課題において，外乱のタイミングの予 告により，予測的姿勢制御としての外乱前の下肢筋活 動量が増加し, 代償的姿勢制御としての外乱後の下肢 筋活動量が低下することを示した。さらに Nakazawa ら ${ }^{10)}$ は, 可動式プラットフォームを用いて $1 \mathrm{~cm}$ の高 さから落下した際の着地時の筋活動の変化を計測し, 落下 3 秒前からカウントダウンを与えた場合, 前脛骨 筋の活動が減少することを示した。一方, Cresswell ら ${ }^{11)}$ はハーネスを用いて体幹を急激に屈曲させる負荷 を加える課題時の体幹の筋反応時間を計測し，外乱の タイミングの教示による影響はなかったと報告した。

Horak ら ${ }^{12)}$ は, 床面が水平前後方向に移動した際の 姿勢制御として足関節戦略および股関節戦略について 明らかにした。また，飯島ら ${ }^{13)}$ は床が前後移動方向に 移動する外乱刺激を漸増することで足関節戦略から股 関節戦略，ステッピング戦略と姿勢戦略が段階的に変 化することを示した。Henry ら ${ }^{14)}$ は床を水平面上 8 方 向に移動させた際の下肢の筋活動を測定し, 姿勢を保 持するために外乱方向に依存した筋活動が生じること を示した。ただし，床の側方移動に対する姿勢制御の 研究は少なく ${ }^{14)}$, 外乱予告を加えた先行研究は, 我々 が涉猟した範囲では見当たらなかった。電車やバスな ど床が急激に側方移動する環境は日常的にも多く，外 乱予告時の姿勢制御を明らかにすることは車内の転倒 事故減少につながる基礎情報になり得る。また，日常
生活においては外乱予告後に全く同じ外乱が生じるこ とは少ないことから, 外乱への適応が少ない環境下で の筋活動量を検討した。

そこで, 本研究の目的は側方への床面移動に対する 外乱予告の有無が下肢筋の筋活動に与える影響につい て検討することとした。

\section{II. 対象と方法}

\section{1. 対 象}

対象は，健常成人男性 13 名，平均年齢は $21.4 \pm 0.5$ 歳, 平均身長は $172.4 \pm 4.6 \mathrm{~cm}$, 平均体重は69.4 414.7 $\mathrm{kg}$ であった。すべての対象者に，書面および口頭に て研究の趣旨と内容についての説明を行った。また, 得られたデー夕ならびに個人情報は研究以外で使用す ることがないことを説明し，同意を得た上で研究を 行った。なお, 本研究は所属機関の研究倫理委員会の 承認を得て実施した（承認番号19-08）。

\section{2. 測定方法}

対象者は, 水平外乱刺激発生装置 (以下, 外乱装置) 上で両足内果間距離約 $15 \mathrm{~cm}$, 両上肢を体側に垂らし た安静立位を保持させた。対象者には床が右側方移動 することを伝えた。対象者の視線は，身体が横に移動 しても前方水平位が保てるように，外乱刺激装置から $2 \mathrm{~m}$ 前方で目線の高さに合わせて横 $2 \mathrm{~m}$ の長さの テープを壁に貼り付け，対象者にテープを注視するよ うに指示した。床の側方移動を行うにあたり予告有条 件と予告無条件の 2 つの条件を設け, 外乱の定義を「立 位姿勢における床面を水平右側方向に動かすこと」と した。予告有条件では，床面が水平右側方向へ移動す ることを事前に告知し，10秒間の安静時立位を保持さ せた後，3秒間のカウントダウンを行い，外乱装置を 発車させた。一方，予告無条件では，床面が水平右側 方向へ移動することを告知せず，10秒間の安静時立位 を保持させた後，任意の夕イミングで外乱を加えた。 それぞれ 3 回ずつ測定し, 各測定のインターバルは 120 秒とした。1 回目の測定は予告無条件, 予告有条件の 順に実施し，その後はランダムに実施した。なお，本 研究においては，外乱への適応を含めた調査を目的と しなかったことから外乱および外乱予告への適応の少 ない 1 施行目の測定值を採用した ${ }^{15)}$ 。

\section{3. 水平外乱刺激発生装置}

外乱装置の床面の大きさは縦 $105.5 \mathrm{~cm} \times$ 横 $100 \mathrm{~cm}$ の 
長方形であった。車輪の大きさは直径 $12 \mathrm{~cm}$, モーター は Brushless Motor (Kun ray 350W48V ; Kuray Cycling \& Ebike CO, LTD, China) を使用した。手動の コントローラーを用い, 水平右側方向への外乱装置を 操作させた。外乱装置の重力加速度は $0.05 \mathrm{G}$ で, 側方 への移動距離は $2 \mathrm{~m}$ とした。なお, 設定した重力加 速度はバス発車時の外乱と同程度とした ${ }^{16)}$ 。また，外 乱時の転倒を予防するために安全装置を装着した。

\section{4. 筋電図}

表面筋電図の測定は，筋電計（テレマイオ G2，Noraxon 社製）を用い，サンプリング周波数 $1000 \mathrm{~Hz}$ に て計測した。電極は, ディスポーザブル銀塩化銀電極

(Blue Sensor SP, Ambu 社製) を用い，測定筋は左 右の長腓骨筋, 前脛骨筋, 中殿筋, 長内転筋の計 8 筋 とした。電極貼付位置は, 先行研究 ${ }^{17-18)}$ に基づき, 前 脛骨筋は脛骨外側顆から 4 横指遠位, 長腓骨筋は腓骨 頭より 3 横指遠位部，中殿筋は大転子と腸骨稜を結ぶ 線の近位 $1 / 3$, 長内転筋は大腿内側で恥骨結合と膝 関節を結ぶ線の近位 $1 / 3$, アース電極を右腓骨頭と し, 電極間距離を $2 \mathrm{~cm}$ とした。導出方法は, 双極導 出法とし, 電極貼付の際には, 適切な皮膚処理を行っ た。

\section{5. 加速度計}

外乱装置の加速度の測定は, 3 軸加速度計 (A3AX -sensor，テック技販社製）を用い, サンプリング周 波数 $1000 \mathrm{~Hz}$ にて計測した。加速度計は外乱装置に固 定し, 外乱装置が動き始めたタイミングを同定するこ とを目的に測定した。

\section{6. 解析方法}

水平右側方向への加速度の平均値を $25 \mathrm{msec}$ の区間 ごとに算出した。その後, 静止時の 1 秒間の加速度の 平均值と標準偏差を算出し, 平均值 \pm 3 標準偏差を超 えた值が連続して生じた区間を外乱装置の発車の夕イ ミングとした。

得られた筋電図は, バンドパスフィルタ $(20-500$ $\mathrm{Hz})$ でフィルタ処理し, 全波整流した。外乱刺激装 置が発射したタイミングを 0 とし, 外乱刺激開始の1500msecから+1000msecにおいて, 25msecごとに 積分值 (Integrated Electromyogram, 以下 IEMG) を求めた。その後, IEMGをすべての課題における IEMGの最大值で除すことで正規化し，\%IEMG を算
出した。なお，正規化に用いた IEMGの最大值は 3 回測定した值から求めた。

測定值は，予測の有無による影響が大きい 1 回目の 值から外乱刺激前の安静時の\%IEMG (以下, \% IEMG -rest), 外乱刺激後の最大筋活動量（以下，\%IEMGMax）および筋反応時間を算出した。\%IEMG-restは， 外乱刺激が加わる直前かつ予告を行っている区間を解 析区間とし，外乱刺激開始の-1500msec から -500 $\operatorname{msec} の 1$ 秒間とし，40相内の\%IEMG の平均值を求 めた。\%IEMG-Maxは, 外乱刺激を開始した $0 \mathrm{msec}$ から1000msecを解析区間とし，25msecごとに40相 に分け，40相内での\%IEMGの最大值を\%IEMG-Max とした。また，\%IEMG-maxが生じた相を筋反応時 間（相）として同定した。

\section{7. 統計学的解析}

各筋の \%IEMG-rest，\%IEMG-Max，筋反応時間に おける予測の有無の比較は, 対応のある $\mathrm{t}$ 検定を用い て検討した。なお, 統計学的解析ソフトはSPSS ver. 25 (IBM 社製) を用い，統計学的有意水準は $5 \%$ とした。

\section{III. 結 果}

\%IEMG-Max に関して，予告無条件と比較して予 告有条件では, 左中殿筋, 右前脛骨筋および右長腓骨 筋に扔いて有意に高い数值を示した。筋反応時間に関 しては, 予告無条件と比較して予告有条件では左中殿 筋, 左長内転筋および右長腓骨筋において有意に低い 值であった。\%IEMG-rest については，いずれの筋に おいても予告無条件と予告有条件で有意差は認められ なかった（表 1 )。

\section{IV. 考 察}

本研究は, 床の側方水平外乱刺激に対する予測の有 無が下肢筋の筋活動に与える影響について 1 施行目の 筋活動量を用いて検討した。その結果, 予告無条件と 比較して予告有条件では, 足関節において右長腓骨筋 および右前脛骨筋の\%IEMG-Max が有意に高い值を 示し, 右長腓骨筋において筋反応時間が有意に短縮し た。また, 股関節においては, 左中殿筋の\% IEMG-Max が有意に高い值を示し, 左中殿筋および左長内転筋に おいて筋反応時間が有意に短縮した。

Horak $^{12)}$ らは床の前後方向の水平外乱時に, 実際の 外乱の大きさよりも外乱を大きく見積もった対象者は 姿勢調節としての筋活動量が大きくなり, 繰り返しに 
表 1 発車予告の有無による筋活動量および筋反応時間の比較

\begin{tabular}{|c|c|c|c|c|}
\hline & & 予告無条件 & 予告有条件 & $\mathrm{p}$ 值 \\
\hline \multirow[t]{3}{*}{ 右前脛骨筋 } & \%IEMG-rest（\%) & $11.3 \pm 8.8$ & $11.8 \pm 8.7$ & 0.52 \\
\hline & \%IEMG-Max (\%) & $45.5 \pm 16.9$ & $61.6 \pm 14.0^{*}$ & 0.04 \\
\hline & 筋反応時間 (相) & $14.5 \pm 5.6$ & $12.9 \pm 4.9$ & 0.33 \\
\hline \multirow[t]{3}{*}{ 左前脛骨筋 } & \%IEMG-rest(\%) & $11.9 \pm 10.1$ & $11.3 \pm 9.6$ & 0.60 \\
\hline & \%IEMG-Max (\%) & $51.0 \pm 23.5$ & $61.6 \pm 14$ & 0.19 \\
\hline & 筋反応時間 (相) & $14.7 \pm 8.7$ & $11.7 \pm 5.7$ & 0.29 \\
\hline \multirow[t]{3}{*}{ 右長腓骨筋 } & \%IEMG-rest(\%) & $9.5 \pm 10.5$ & $9.6 \pm 9.6$ & 0.85 \\
\hline & \%IEMG-Max (\%) & $39.3 \pm 16.8$ & $52.8 \pm 20.7^{*}$ & 0.04 \\
\hline & 筋反応時間 (相) & $14.7 \pm 5.6$ & $11.1 \pm 3.6^{*}$ & 0.01 \\
\hline \multirow[t]{3}{*}{ 左長腓骨筋 } & \%IEMG-rest (\%) & $9.1 \pm 15.7$ & $9.8 \pm 15.2$ & 0.52 \\
\hline & \%IEMG-Max (\%) & $46.2 \pm 29.4$ & $47.0 \pm 20.9$ & 0.91 \\
\hline & 筋反応時間 (相) & $14.3 \pm 6.4$ & $13.7 \pm 8.4$ & 0.80 \\
\hline \multirow[t]{3}{*}{ 右中殿筋 } & \%IEMG-rest（\%) & $8.7 \pm 5.6$ & $9.0 \pm 6.2$ & 0.80 \\
\hline & \%IEMG-Max (\%) & $48.9 \pm 28.0$ & $46.0 \pm 26.6$ & 0.66 \\
\hline & 筋反応時間 (相) & $16.7 \pm 7.1$ & $15.4 \pm 8.5$ & 0.51 \\
\hline \multirow[t]{3}{*}{ 左中殿筋 } & \%IEMG-rest (\%) & $6.8 \pm 8.6$ & $8.1 \pm 9.1$ & 0.22 \\
\hline & \%IEMG-Max (\%) & $51.3 \pm 12.4$ & $72.7 \pm 24.6^{*}$ & $\mathrm{p}<0.01$ \\
\hline & 筋反応時間 (相) & $17.7 \pm 8.6$ & $10.4 \pm 3.3^{*}$ & 0.01 \\
\hline \multirow[t]{3}{*}{ 右長内転筋 } & \%IEMG-rest (\%) & $9.5 \pm 5.6$ & $11.6 \pm 7.6$ & 0.08 \\
\hline & \%IEMG-Max (\%) & $47.0 \pm 27.0$ & $49.7 \pm 30$ & 0.77 \\
\hline & 筋反応時間 (相) & $19.7 \pm 9.3$ & $16.0 \pm 7.1$ & 0.08 \\
\hline \multirow[t]{3}{*}{ 左長内転筋 } & \%IEMG-rest (\%) & $14.6 \pm 10.5$ & $13.8 \pm 10.9$ & 0.49 \\
\hline & \%IEMG-Max (\%) & $43.5 \pm 27.2$ & $35.2 \pm 21.3$ & 0.08 \\
\hline & 筋反応時間 (相) & $23.3 \pm 9.7$ & $16.5 \pm 6.5^{*}$ & 0.02 \\
\hline
\end{tabular}

\%IEMG-rest : 安静時の筋活動量, \%IEMG-max : 外乱後の最大筋活動量

$*: \mathrm{p}<0.05$

よって減少することを明らかにしている。河石ら ${ }^{15}$ は, 歩行中に打ける床面素材の変化させた際の筋活動を測 定し， 3 施行目と比較して 1 施行目で筋活動が大きく なったことを明らかにした。一方, Claudino ら ${ }^{9} や$ Nakazawa ら $^{10}$ の研究では, 複数回の平均值を代表值 とし, 外乱予告によって筋活動の開始の早期化や外乱 後の筋活動量の減少を示した。また，測定の順序とし て予告無条件後に予告有条件を実施したことから，予 告有条件では外乱を経験して㧍り，施行回数は少ない ものの経験による影響が生じた。しかし，先行研究 ${ }^{15)}$ では外乱の経験によって筋活動量が減少したが, 本研 究結果では外乱を 1 回経験した予告有条件において\% IEMG-Maxが増加しており，\%IEMG-Maxの増加は 予告による影響が大きいと考えられる。以上のことか ら, 本研究では外乱への適応が不十分な条件の代表值 を用い，外乱予告によって外乱の大きさを実際よりも 大きく見積もった結果, 予告有条件で姿勢保持に関与 する筋の\%IEMG-Max が有意に高值になったと推察 される。また, 本研究結果で用いた\%IEMG-Maxは,
瞬間的な筋活動量で姿勢制御に要した筋活動量の総和 ではないことから，姿勢保持に要した筋活動量につい ては言及できない。ただし，予告によって外乱に抗す る筋の\%IEMG-Max が早期化したことから，外乱後 の COP の偏位が小さくなり, 姿勢を保持する筋活動 量の総和が小さくなることも予想され, 今後外乱後の 筋活動量の総和についても検討を加えたい。

外乱を制動する姿勢制御について, 福井ら ${ }^{19}$ は体幹 が後傾している場合，股関節上部の重心は股関節より 後方に位置するため, 重心にかかる重力は股関節を伸 展させるモーメントとなり，身体がこの位置を保つた めには股関節屈曲モーメントを発揮することで平衡を 保つと述べている。本研究では, 床が右側方向へ移動 することで左股関節を内転させる外部モーメントが作 用する。つまり，左股関節上部の重心は左股関節より 左側に位置することから外部モーメントして左股関節 内転モーメントが生じ，これに対して内部モーメント として左股関節外転筋を発揮させることで姿勢制御を 行ったと推測される。これらのことから, 予告によっ 
て右側方外乱刺激に対する姿勢制御を行う左中殿筋の \%IEMG-Max が強調されたと考えられる。また, Winter $ら^{20)}$ は, 左右へ荷重を移動させる制御に関して, 足関節戦略よりもむしろ股関節外転筋群と内転筋群の 活動が寄与して可能性を述べている。このことから, 予告有条件において左中殿筋抒よび左長内転筋の筋反 応時間が短縮した要因は, 外乱刺激に対する予測によ り，姿勢保持に関与する左中殿筋および左長内転筋の 筋反応時間が短縮し, 左下肢による荷重のコントロー ルを早期に行った結果であると推察した。

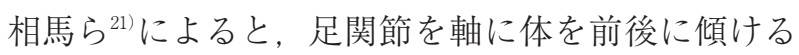
前後重心移動課題の振幅を増大させたところ, 若年者 は前脛骨筋と腓腹筋ともに筋活動を高め, 足関節周囲 筋の同時収縮が高まったと報告している。本研究にお いても, 右側方向への外乱に対し, 足部の内外反の作 用をもつ右前脛骨筋および右長腓骨筋の両筋の筋活動 を高め, 足部の安定性を得ていると考える。また，予 告有条件において, 右側方向への外乱に伴う右下腿の 左傾斜に対し, 右長腓骨筋の筋活動を早期化させるこ とで右下腿の左傾斜を制動し, 重心を右側方向へ移動 させたと考えられる。

予測的姿勢制御について, Horak ら ${ }^{14}$ は両側上肢に 重りをつけ，上肢を素早く動かした際に姿勢筋の筋活 動量が高まったことを報告している。一方, Lee ら ${ }^{22)}$ は上肢の運動速度が小さい場合や運動負荷が小さい場 合は，予測的姿勢制御としての筋活動は減少あるいは 消失することが明らかにしている。さらに, 外乱に対 する対象者の年齢, 能力や経験などによっても, 予測 的姿勢制御が変化することが示されている ${ }^{23-24)}$ 。これ らのことから, 本研究において外乱予告の有無によっ て\%IEMG-restに有意差が生じなかった要因として, バランス能力が高い若年健常男性にとって, 本研究で 加えた側方外乱刺激は予測的姿勢制御として安静時の 筋活動量を高めるほどの課題ではなかったためと考え られる。

本研究において予告無条件の 1 施行目と比較して予 告有条件の 1 施行目では, 予測的姿勢制御ではなく代 償的姿勢制御として, 外乱の方向に依存した筋の最大 筋活動量の増加や筋反応時間の短縮により姿勢を制御 することが明らかになった。このことから，床が側方 へ移動するバス抢よび電車などの発車時に, 注意を促 すアナウンスなどの予測を促すことを徹底することで, 転倒リスクの減少につながる可能性を示した。ただし,

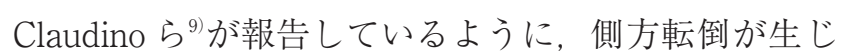

やすい高齢者と若年者の側方外乱の姿勢制御は異なっ ており，本研究結果を高齢者に当てはめることができ ないことから，今後高齢者を対象とした調査を行いた い。本研究の限界として, 予告有条件に打いて外乱へ の適応が生じている可能性があり, 今後施行回数も含 めた検討を加えたい。

\section{引用文献}

1)弓岡光徳, 村田伸, 前田昭宏・他 : 最新のボバースアプロー チの紹介ー立位から臥位への姿勢変換を中心に一。西九州 リハビリテーション研究, 2012, 5 : 67-77.

2)Scovil CY, Zettel JL, Maki BE: Stepping to recover balance in complex environments: Is online visual control of the foot motion necessary or sufficient?. Neuroscience Letters, 2008, 445: 108-112.

3) Henry SM, Fung J, Horak FB: Effect of stance width on multidirectional postural responses. Journal of Neurophysiology, 2001, 85: 559-570.

4) Cordo PJ, Nashner LM: Properties of postural adjustments associated with rapid arm movements. Journal of Neurophysiology, 1982, 47: 287-302.

5) Brauer SG, Woollacott M, Shumway-Cook A: The influence of a concurrent cognitive task on the compensatory stepping response to a perturbation in balance-impaired and healthy elders. Gait Posture, 2002, 15: 83-93.

6) Brown LA, Shumway-Cook A, Woollacott MH: Attentional demands and postural recovery: The effects of aging. J Gerontol A Biol Sci Med Sci, 1999, 54(4): M 165-M 71.

7) Ackermann H, Scholz E, Koehler W, et al.: Influence of posture and voluntary background contraction upon compound muscle action-potentials from anterior tibial and soleus muscle following transcranial magnetic stimulation. Electroencephalogr. Clin. Neurophysiol, 1991, 81: 71-80.

8) McChesney JW, Sveistrup H, Woollacott MH: Influence of auditory precuing on automatic postural responses. Exp Brain Res, 1996, 108: 315-320.

9) Claudino R, dos Santos EC, Santos MJ, et al.: Compensatory but not anticipatory adjustments are altered in older adults during lateral postural perturbations. Clinical Neurophysiology, 2013, 8: 1628-1637.

10) Nakazawa K, Kawashima N, Akai M: Effect of different preparatory states on the reflex responses of ankle flexor and extensor muscles to a sudden drop of support surface during standing in humans. J Electromyogr Kinesiol, 2009, 19: 782-788.

11) Cresswell AG, Oddsson L, Thorstensson A: The influence of sudden perturbations on trunk muscle activity and intraabdominal pressure while standing. Exp Brain Res, 1994, 98 (2): 336-341.

12) Horak FB, Esselman PE, Anderson ME, et al.: The effect of movement velocity, mass displaced and tasks certainty on associated postural adjustments made by normal and hemiplegic individuals. J. Neurophysiol., 1984, 62: 841-853. 
13)飯島賢一, 関根正樹, 田村俊世: 漸増する水平外乱刺激に 対する姿勢応答. 生体医工学, 2009, 47(1)：70-76.

14) Henrry SM, Horak FB: EMG responses to maintain stance during multidirectional surface translations.J Neurophysiol, 1998, 80(4): 1939-1950.

15)河石 優, 福本貴彦, 森岡 周 ·歩行中における床面素材 の変化に対する運動パターンの適応過程. 理学療法学, 2013, 40(3)，161-168.

16)戦略的イノベーション創造プログラム：沖縄の交通環境下 に扔ける公共バスのより高度な自動運転制御の実現に向け た調査. https://www.sip-adus.go.jp/file/301s_s.pdf（閲覧 日2021年 1 月30日)

17)隈元庸夫, 世古俊明, 田中昌史・他：両脚立位での骨盤側 方移動が股関節周囲筋活動に及ぼす影響. 理学療法科学, 2014, 29(3):371-375.

18)山口剛司, 高崎恭輔, 大工谷新一 : 足底圧中心変化に伴う 足部周囲筋の積分值相対值変化. 関西理学療法, 2005, 5 : 103-108.

19) 福井勉：姿勢保持とバイオメカニクス. 総合リハ, 2008, 36 (2) : 121-125.

20) Winter DA, Prince F, Sterior P: Medial-lateral and anteriorposterior motor responses associated with center of pressure changes in quiet standing. Neurosci Res Commum, 1993, 12: 141-148.

21) 相馬優樹, 衣笠隆, 漆畑俊哉・他 : 重心移動課題における 足関節筋の同時収縮に及ぼす加齢の影響. 体力科学, 2010, $59: 143-156$.

22) Lee W.A. : Anticipatory control of posture and task muscles during rapid arm flexion. J. Mot.Behav, 1980, 12: 185-196.

23) Aruin AS, Latash ML: Anticipatory postural adjustments during self-initiated perturbations of different magnitude triggered by a standard motor action. Electroencephalogr Clin Neurophysiol, 1996, 101: 497-503.

24) Kanekar N, Aruin AS: The effect of aging on anticipatory postural control. Exp Brain Res, 2014, 232(2): 1127-1136. 